\title{
Central Nervous System Epithelioid Hemangioendothelioma
}

National Cancer Institute

\section{Source}

National Cancer Institute. Central Nervous System Epithelioid Hemangioendothelioma.

NCl Thesaurus. Code C129536.

A low-grade malignant blood vessel neoplasm that arises from the central nervous system. It is characterized by the presence of epithelioid endothelial cells. 